\title{
A rapid and efficient method of fungal genomic DNA extraction, suitable for PCR based molecular methods
}

\author{
Aamir S, Sutar S, Singh SK, Baghela A
}

National Fungal Culture Collection of India, Biodiversity and Palaeobiology Group, Agharkar Research Institute, Gopal Ganesh Agarkar Road, Pune, India 411004

Aamir S, Sutar S, Singh SK, Baghela A 2015 - A rapid and efficient method of fungal genomic DNA extraction, suitable for PCR based molecular methods. Plant Pathology \& Quarantine 5(2), 74-81, Doi 10.5943/ppq/5/2/6

\begin{abstract}
We report a rapid and efficient method of genomic DNA extraction from filamentous fungi with high-throughput potential. The method involves disruption of fungal cell by bead beating in a homogenizer, followed by RNase treatment, phenol: chloroform: Isoamyl alcohol extraction and precipitation with isopropanol. The method does not involve any enzymatic digestion and it can be completed within 2.5 hours. The method yielded good quality and quantity $(60 \mu \mathrm{g}-230 \mu \mathrm{g} / 200 \mathrm{mg}$ of wet fungal mass) of the DNA. Being a closed system of gDNA extraction, our method has been found to be useful in avoiding the laboratory borne contamination during DNA extraction. The extracted DNA was found to be suitable for PCR based molecular methods like single and multicopy gene amplification and RAPD analysis.
\end{abstract}

Key words - $\beta$-tubulin - DNA isolation - Fungi - ITS-rDNA - RAPD

\section{Introduction}

The development of PCR-based molecular techniques has become the method of choice for identification \& characterization of fungi. It becomes important to isolate genomic DNA (gDNA) of superior quality and quantity for analyzing through PCR based applications. The major challenge for isolation of such DNA from fungi lies in breaking the rigid cell walls, as, they are often resistant to traditional DNA extraction procedures (Fredricks et al. 2005). Generally there are two major steps involved in fungal genomic DNA extraction, which are disruption of cell wall and extraction followed by purification of genomic DNA. The extraction of genomic DNA is usually done with cetyl trimethyl ammonium bromide (CTAB) extraction buffer (Doyle \& Doyle 1987) followed by purification through phenol/chloroform extraction and precipitation with isopropanol or ethanol (Ashktorab \& Cohen 1992). Out of several methods applied for breaking cell walls, one of the most common methods is grinding of mycelia using glass rods or liquid nitrogen (Lee et al. 1988, Wu et al. 2001). Magnetic beads (Faggi et al. 2005), microwave exposure (Goodwin \& Lee 1993), dry ice (Griffin et al. 2002), benzyl chloride (Xue et al. 2006), enzyme digestion (Li et al. 2002), beadvortexing/SDS lysis and high speed cell disruption (Sambrook \& Russel 2001, Muller et al. 1998) and sometimes in combination (Zhang et al. 2008) have been used by some researchers. However, 
most of these protocols and techniques results in variable quality and quantity of DNA and are time consuming as well.

In recent years, studies on fungal communities and fungal diversity studies have increased rapidly (Dighton et al. 2005). The large scale community studies often require the identification of a large number of fungal species and strains, and for molecular identification of such a large numbers of fungal isolates, the genomic DNA also needs to be isolated in a high-throughput manner. Barring few commercially available DNA extraction kits, many of the available fungal gDNA extraction methods are time consuming, and are not suitable for a large number of samples. In addition, for a fungal culture collection or a fungal molecular identification service provider like us (National Fungal Culture Collection of India [NFCCI], Pune, India), the timely identification also depends upon, how fast one can get the fungal gDNA. A rapid method of gDNA extraction would effectively reduce the time for DNA sequencing based molecular identification of fungi. Therefore, we developed a rapid method of fungal gDNA extraction with high throughput potential.

\section{Materials \& Methods}

\section{Fungal strains}

A total number of fifteen fungal strains available at National Fungal Culture Collection of India (NFCCI) - Agharkar Research Institute, Pune, India were included in the study (Table 1).

\section{Fungal genomic DNA extraction}

The genomic DNA was extracted from five to seven days old fungal cultures grown either in liquid broth or culture plates. The fungal mass from the culture plate was scraped out with the help of a fine spatula and fungal mass from the culture broth was obtained by filtering the culture broth through a $10 \mathrm{ml}$ syringes containing glass wool that will allow the broth to pass through, while retaining the fungal mass. The fungal mass obtained from the culture plate or broth was placed in a $2 \mathrm{ml}$ tube containing a ceramic pestle, $60-80 \mathrm{mg}$ sterile glass beads $(425-600 \mu \mathrm{M}$, Sigma) and lysis buffer (100 mM Tris $\mathrm{HCl}$ [pH8.0], 50mM EDTA, 3\% SDS). Homogenization of fungal mass was done twice in a FastPrep®-24 tissue homogenizer (MP Biomedicals, USA) at 6 $\mathrm{M} / \mathrm{S}$ for $60 \mathrm{sec}$. The resulting fungal tissue homogenate was centrifuge at 13,000 rpm for $10 \mathrm{~min}$ and supernatant was transferred to a fresh microcentrifuge tube. To the supernatant, 2 of RNase A $(10 \mathrm{mg} / \mathrm{ml})$ was added and incubated at $37^{\circ} \mathrm{C}$ for $15 \mathrm{~min}$. After the RNase A treatment, equal volume of phenol: chloroform: Isoamyl alcohol (25:24:1) was added and mixed well, followed by centrifugation at 13,000 rpm for $10 \mathrm{~min}$ (Note: this step can be repeated once more to completely get rid of proteins/cell debris). The upper aqueous layer was taken in a fresh micro centrifuge tube and then equal volume of $100 \%$ ethanol was added. Following precipitation at $-20^{\circ} \mathrm{C}$ for $30 \mathrm{~min}$, the whole content was centrifuged at $12,000 \mathrm{rpm}$ for $10 \mathrm{~min}$ to pellet down the DNA. The DNA pellet was washed with $70 \%$ ethanol and centrifuged at 12,000 rpm for $5 \mathrm{~min}$. The DNA pellets were air dried and dissolved in $1 \times$ TE buffer.

\section{Quantity and quality determination}

The quantity of the extracted gDNA was determined by measuring the absorbance at 260 nm using Thermo Scientific Nano Drop 1000 spectrophotometer. The quality of extracted gDNA was accessed by subjecting them on $0.8 \%$ agarose gel electrophoresis and suitability for downstream application in RAPD (Random Amplified polymorphic DNA) analysis, single copy gene and multi-copy gene amplification. The PCR reactions for RAPD analysis were performed in a $25 \mu 1$ reaction volume containing $16 \mu \mathrm{l}$ PCR grade water (Sigma), 100ng of genomic DNA, $2.5 \mu 1$ of $10 \times$ reaction buffers, $2.5 \mu \mathrm{l}$ of $10 \mathrm{mM}$ dNTPs mix (Sigma-Aldrich), $2 \mu 1(10 \mathrm{pmol} / \mu \mathrm{l})$ of random decamer oligonucleotide primer OPA-1 (5'-CAGGCCCTTC-3'), and $1 \mu 1$ (5 U/ $\mu$ l) of Taq DNA polymerase (Sigma-Aldrich). Amplification was performed in an Eppendorf Master Cycler (Eppendorf, Hamburg). The PCR cycling conditions consisted of an initial denatuartion step of 
$94^{\circ} \mathrm{C}$ for $2 \mathrm{~min}$ and subjected to 40 cycles of the following program $94^{\circ} \mathrm{C}$ for $30 \mathrm{~s}, 37^{\circ} \mathrm{C}$ for $1 \mathrm{~min}$, $72^{\circ} \mathrm{C}$ for $2 \mathrm{~min}$ and final extension at $72^{\circ} \mathrm{C}$ for $10 \mathrm{~min}$.

Table 1 Fungal strains used in the study, their NFCCI numbers, source and place of isolation and DNA yield

\begin{tabular}{|c|c|c|c|c|}
\hline $\begin{array}{l}\text { S. } \\
\text { No. }\end{array}$ & Fungal strains & $\begin{array}{l}\text { NFCCI* } \\
\text { accession } \\
\text { numbers }\end{array}$ & Source \& place & $\begin{array}{l}\text { DNA yield } \\
\mu \mathrm{g} / 200 \mathrm{mg} \text { of } \\
\text { fungal mass }\end{array}$ \\
\hline 1 & Cladosporium tenuissimum & 3497 & $\begin{array}{l}\text { Bat guano, Uttar Pradesh } \\
\text { (U.P.), India }\end{array}$ & 110 \\
\hline 2 & Penicillium concentricum & 3564 & Bat guano, U.P., India & 115 \\
\hline 3 & Emericella variecolor & 3496 & Bat guano, U.P., India & 80 \\
\hline 4 & Aspergillus oryzae & 3495 & Bat guano, U.P., India & 190 \\
\hline 5 & Aspergillus flavus & 3499 & Bat guano, U.P., India & 195 \\
\hline 6 & Aspergillus terreus & 3547 & Soil, Kerala, India & 112 \\
\hline 7 & Curvularia affinis & 3523 & $\begin{array}{l}\text { Rotten bamboo, Assam, } \\
\text { India }\end{array}$ & 110 \\
\hline 8 & Rigidoporus vinctus & 3522 & $\begin{array}{l}\text { Rotten bamboo, Assam, } \\
\text { India }\end{array}$ & 120 \\
\hline 9 & Inonotus pachyphloeus & 3571 & Rotten bark, Assam, India & 155 \\
\hline 10 & Curvularia lunata & 3548 & $\begin{array}{l}\text { Turmeric leaf, Tamil } \\
\text { Nadu, India }\end{array}$ & 60 \\
\hline 11 & Earliella scabrosa & 3584 & Tamil Nadu, India & 220 \\
\hline 12 & Penicillium oxalicum & 3582 & West Bengal, India & 220 \\
\hline 13 & Fusarium incarnatum & 3598 & $\begin{array}{l}\text { Crossandra, Tamil Nadu, } \\
\text { India }\end{array}$ & 225 \\
\hline 14 & Fusarium phaseoli & 3238 & Papaya root, Bihar, India & 230 \\
\hline 15 & Fusarium sp. & 3634 & $\begin{array}{l}\text { Terminalia } \\
\text { Tripura India }\end{array}$ & 225 \\
\hline
\end{tabular}

* NFCCI - National Fungal Culture Collection of India, Agharkar Research Institute, Pune, India.

A single copy $\beta$-tubulin gene was amplified from the extracted gDNA using the primers described by Chauhan et al. 2007. The PCRs were performed in a $25 \mu 1$ reaction volume containing $16 \mu \mathrm{l}$ PCR grade water (Sigma), $2 \mu \mathrm{l}(10 \mathrm{pmol} / \mu \mathrm{l})$ each of $\beta$-tubulin gene specific forward (5'GGTAACCAAATCGGTGCTGCTTTC-3') and reverse (5'-ACCCTCAGTGTAGTGACCCTT GGC-3') primers, $2.5 \mu 1$ of $10 \times$ reaction buffers, $2.5 \mu 1$ of $10 \mathrm{mM}$ dNTPs mix (Sigma-Aldrich), $1 \mu 1$ (5 U/ $\mu$ l) Taq DNA polymerase (Sigma-Aldrich), and approximately 20-50 ng of gDNA. PCR was performed in an Eppendorf Master Cycler (Eppendorf, Hamburg) following the conditions described by Chauhan et al. 2007.

The multi-copy ITS-rDNA gene amplification was performed with universal fungal primer pairs ITS4/ITS5 (White et al. 1990). The PCRs were performed in a $25 \mu 1$ reaction volume containing 16 $\mu$ PCR grade water (Sigma), $2.5 \mu \mathrm{l}$ PCR buffer $(10 \times), 2.5 \mu 1$ of $10 \mathrm{mM}$ dNTPs mix (Sigma-Aldrich), $1 \mu \mathrm{l}$ of each primer $(20 \mathrm{pmol} / \mu \mathrm{l}), 1 \mu \mathrm{l}(5 \mathrm{U} / \mu \mathrm{l})$ of Taq polymerase (SigmaAldrich) along with 20-50ng of template DNA. PCR was performed in an Eppendorf Master Cycler (Eppendorf, Hamburg). The amplification program consisted of an initial denaturation step at $95{ }^{\circ} \mathrm{C}$ for $5 \mathrm{~min}$ followed by 30 cycles of denaturation at $95{ }^{\circ} \mathrm{C}$ for $1 \mathrm{~min}$, annealing for 30 seconds at $55{ }^{\circ} \mathrm{C}$ and extension for $1 \mathrm{~min}$ at $72{ }^{\circ} \mathrm{C}$. A final extension step at $72{ }^{\circ} \mathrm{C}$ for 7 min was included at the end of the amplification. All PCR products were electrophoresed, imaged and analyzed in a Gel Documentation System (Syngene Inc. Cambridge). 


\section{Results \& discussion}

The proposed fungal gDNA extraction method yielded good quality high molecular weight DNA from filamentous fungi, as evident upon agarose gel electrophoresis (Fig. 1A). The total genomic DNA yield was found to be in range of $60 \mu \mathrm{g}-230 \mu \mathrm{g} / 200 \mathrm{mg}$ of wet fungal mass (Table1). The DNA yield was found to be comparable with the previously described methods (Abd-elsalam et al. 2003, Al-Samarrai et al. 2000, Amer et al. 2011, Faggi et al. 2005, Mishra et al. 2014, Griffin et al. 2002, Griffiths et al. 2006, Karakousis et al. 2006, Karthikeyan et al. 2010, Lee et al. 1988, Liu et. al. 2000, Mendoza et al. 2010, Mishra et al. 2008, Moller et al. 1992, Nawrot et al. 2010, Płaza et al. 2004, Prabha et al. 2013, Van Burik et al. 1998, Zhang et al. 2010) (Table 2). The gDNA from yeasts could also be isolated by using the developed protocol (data not shown). The isolated DNA was found to be suitable for various downstream PCR based molecular biology applications. We could get successful amplification by using random decamer primer OPA-1 in RAPD analysis for all the fifteen samples tested (Fig. 1B). The ITS (internal transcribed spacer) region of rDNA has been considered as a de facto barcode for most of the fungi (Schoch et al. 2012). Our developed method could successfully amplify a multi-copy (ITS-rDNA) gene, which confirmed that the extracted DNA could be used for molecular identification as well as phylogenetic studies (Fig. 1C). Protein-coding single-copy genes are also widely used in mycology, for both higher-level phylogenetic studies and species level identification, for example translation elongation factor $1-\alpha$ has been used for Fusarium (O'Donnell et al. 2010) and $\beta$-tubulin for Penicillium (Frisvad \& Samson 2004). The DNA isolated by the proposed method could be used to amplify a portion (400-450bp) of a single copy gene like $\beta$-tubulin from the tested fungi, which shows that the quality and quantity of the isolated DNA is suitable even for single copy protein coding gene amplification as well (Fig. 1D).
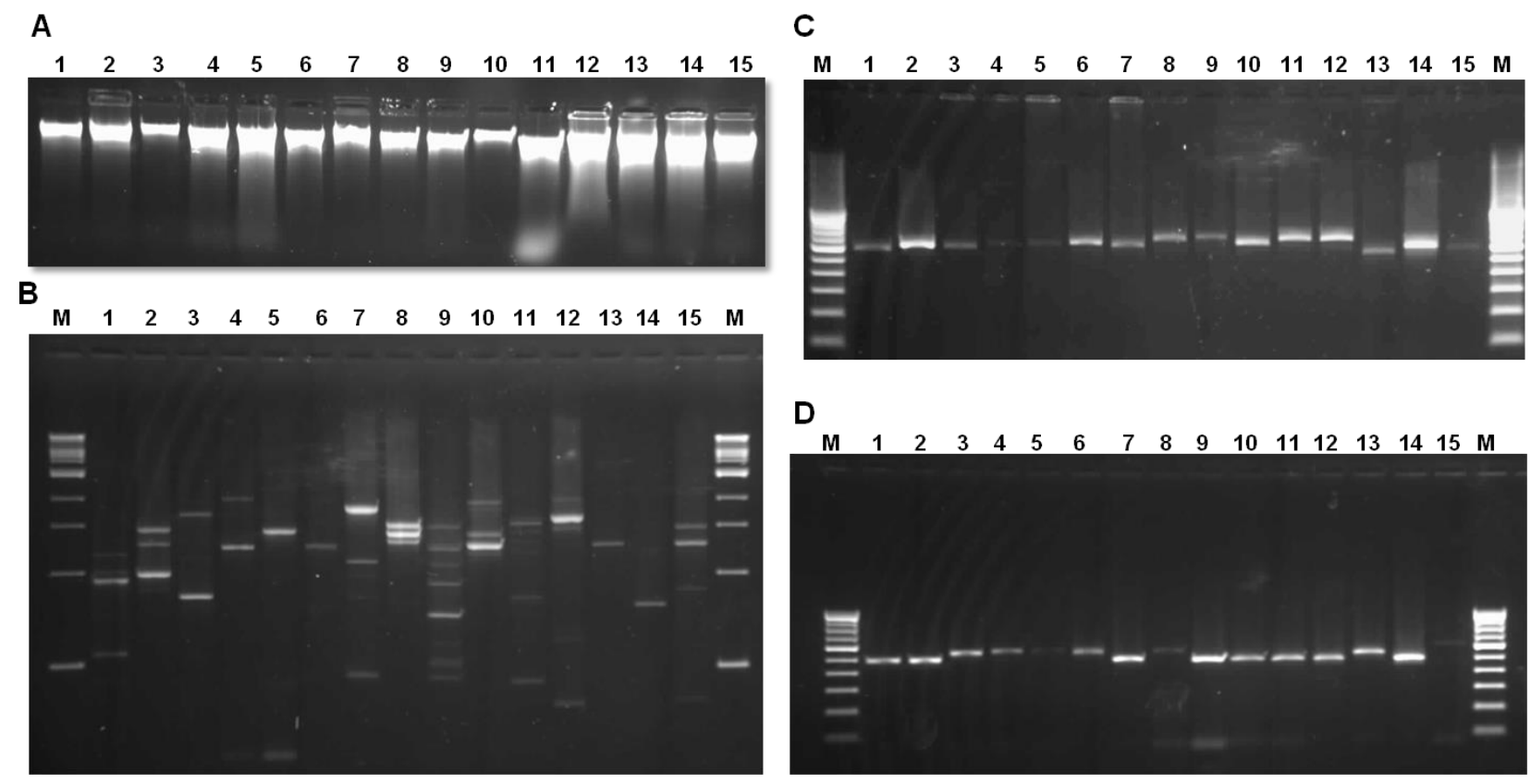

Fig 1 - A: Agarose gel electrophoresis of gDNA, B: The RAPD profile with the primer OPA01 of the fungal strains studied, $\mathrm{C}$ : Agarose gel electrophoresis of multi-copy gene (ITS-rDNA) amplicons of the fungal strains studied, D: Agarose gel electrophoresis of single copy gene ( $\beta$ tubulin) amplicons of the fungal strains studied. Lane 1 to 15; Cladosporium tenuissimum, Penicillium concentricum, Emericella variecolor, Aspergillus oryzae, Aspergillus flavus, Aspergillus terreus, Curvularia affinis, Rigidoporus vinctus, Inonotus pachyphloeus, Curvularia lunata, Earliella scabrosa, Penicillium oxalicum, Fusarium incarnatum, Fusarium phaseoli, Fusarium sp., and M- 100bp DNA ladder \& M- Supermix DNA ladder (Merck-Genei). 
Table 2 Comparison of proposed method of fungal genomic DNA extraction with previously described methods*

\begin{tabular}{|c|c|c|c|c|c|}
\hline Authors & Method type & Duration & $\begin{array}{l}\text { Starting } \\
\text { material }\end{array}$ & Yield & Fungal coverage \\
\hline Proposed method & Manual & $2 \mathrm{~h} 30 \min$ & $200 \mathrm{mg}$ & $\begin{array}{c}60 \mu \mathrm{g}-230 \mu \mathrm{g} / 200 \mathrm{mg} \text { of } \\
\text { fungal mass }\end{array}$ & Multiple fungi \\
\hline $\begin{array}{l}\text { Abd-elsalam et al., } \\
2003\end{array}$ & Manual & $4 \mathrm{~h}$ & N.A. & $4-6 \mu \mathrm{g}$ & Fusarium species \\
\hline Al-Samarrai et al 2000 & Manual & $1 \mathrm{~h}$ & $30 \mathrm{mg}$ & $\begin{array}{l}0.34-0 \cdot 87 \mu \mathrm{g} \text { DNA } / \mathrm{mg} \\
\text { freeze-dried mycelium }\end{array}$ & $\begin{array}{l}\text { A. niger, A. flavus, } F \text {. graminarum, Neotyphodium lolii, } \\
\text { Penicillium citrinum and Rhizopus nigricanes }\end{array}$ \\
\hline Amer et al., 2011 & Manual & 1h $45 \mathrm{~min}$ & $50 \mathrm{mg}$ & $20-40 \mu \mathrm{g} / 100 \mu \mathrm{l}$ & $\begin{array}{l}\text { Rhizoctonia sp., Fusarium sp., Trichoderma sp., Aspergillus } \\
\text { sp., Ulocladium sp., Penicillium sp. }\end{array}$ \\
\hline Faggi et al., 2005 & Manual + kit & N.A. & N.A. & $223-5684 \mu \mathrm{g} / \mathrm{ml}$ & C. albicans, C. neoformans and dermatophytes \\
\hline Mishra et al., 2014 & Manual & N.A. & $200 \mathrm{mg}$ & $\begin{array}{l}310-1879 \mu \mathrm{g} / \mathrm{g} \text { dried } \\
\text { mycelium }\end{array}$ & $\begin{array}{l}\text { Aspergillus fumigatus, A. niger, A. flavus, A. terreus, A. } \\
\text { awamori, A. ficcum. }\end{array}$ \\
\hline Griffin et al., 2002 & Manual + kit & N.A. & $<3 \mathrm{mg}$ & N.A. & $\begin{array}{l}\text { Fusarium sp., Cladosporium sp., Curvularia sp., Sclerotium } \\
\text { sp., Aspergillus sp., Coccodinium bartschii }\end{array}$ \\
\hline Griffiths et al 2006 & Manual + kit & $3 \mathrm{~h}$ & N.A. & 10 conidia & A. fumigatus conidia \\
\hline Karakousis et al., 2006 & Manual + kit & N.A. & $10-15 \mathrm{mg}$ & $2.5-10 \mu \mathrm{g}$ & Multiple fungi \\
\hline Karthikeyan et al. 2010 & & $3 \mathrm{~h}$ & $50 \mathrm{mg}$ & $5-10 n g$ & Fusarium sp., Bipolaris sp., Verticillium sp., Aspergillus \\
\hline Lee et al., 1988 & Manual & N.A. & $\begin{array}{l}60-100 \mathrm{mg} \\
\text { dry, or } 0.5- \\
1.0 \mathrm{~g} \text { wet }\end{array}$ & $\begin{array}{l}200 \mathrm{ug} \text { DNA/0.1 g } \\
\text { lyophilized mycelium }\end{array}$ & Multiple fungi \\
\hline Liu et. al., 2000 & Manual & $1 \mathrm{~h}$ & N.A. & N.A. & Multiple fungi \\
\hline Mendoza et al., 2010 & Manual & 1h $30 \mathrm{~min}$ & $10 \mathrm{mg}$ & 8.6-9.3 $\mu \mathrm{g} / \mathrm{mg}$ fresh weight & Fusarium oxysporum, Pyrenochaeta terrestris \\
\hline Mishra et al., 2008 & Manual & N.A. & $50 \mathrm{mg}$ & $\begin{array}{l}0.55-0.92 \mu \mathrm{g} \text { DNA/ mg } \\
\text { freeze dried mycelia }\end{array}$ & $\begin{array}{l}\text { F. solani, Colletotrichum capsici Rhizactonia solani, } \\
\text { Phytophthora colocasiae, Pythium aphanidermatum }\end{array}$ \\
\hline Moller et al., 1992 & Manual & N.A. & $30-60 \mathrm{mg}$ & $\begin{array}{l}(100 \mu \mathrm{g} / 30 \mathrm{mg} \text { dried } \\
\text { mycelium })\end{array}$ & Multiple fungi \\
\hline Muller et al., 1998 & Manual + kit & N.A. & $\begin{array}{c}10^{7}-10^{8} \\
\text { conidia/cells }\end{array}$ & $1-49 \mu \mathrm{g} / \mathrm{ml}$ & $\begin{array}{l}\text { C. albicans, } C \text {. neoformans, } T \text {. beigelii, A. fumigatus, } F \text {. } \\
\text { solani, } S . \text { cerevisiae, } P \text {. boydii, } R \text {. arrhizus }\end{array}$ \\
\hline Nawrot et al., 2010 & Kits & N.A. & N.A. & $10^{1}-10^{2}$ spores & A. fumigatus spores \\
\hline Płaza et al., 2004 & Manual & $2 \mathrm{~h}$ & $200-500 \mathrm{mg}$ & N.A. & Multiple fungi \\
\hline Prabha et. al., 2013 & Manual & N.A. & N.A. & $20 \mathrm{mg} / \mathrm{g}$ of mycelium & $\begin{array}{l}\text { Saprolegnia sp., Aphanomyces sp., Aspergillus flavus and } \\
\text { Pythium sp. }\end{array}$ \\
\hline Van Burik et al., 1998 & Manual & N.A. & $30-100 \mathrm{mg}$ & $3.2-81.8 \mu \mathrm{g}$ & Multiple fungi \\
\hline Zhang et al., 2010 & Manual + kit & $40-50 \mathrm{~min}$ & N.A. & N.A. & Ophiocordyceps sinensis specimens \\
\hline
\end{tabular}

*Note: Some of the fungal DNA extraction methods could not be listed in the table because of the space limitations. N.A.: Not available. 
The developed method utilizes bead beating in a tissue homogenizer, which has been found to be very efficient in breaking the fungal cells. There is an obvious one time instrument set up cost involved with the method; however considering the advantages of a tissue homogenizer like FastPrep ${ }^{\circledR}-24$, the instrument cost is justified. Fungal spores, such as conidia from Aspergillus spp. and other molds, might be present in the air. Such airborne spore inoculation during the DNA extraction process could potentially lead to false-positive results, especially if panfungal primers are applied (Löffler et al. 1999). The advantage of a tissue homogenizer is that it is a closed system, wherein, there are no chances of laboratory borne contamination. Therefore, our method will be very useful in avoiding the laboratory borne contamination during DNA extraction. In the current scenario, the numbers of biodiversity studies have increased, wherein; a large number of fungal isolates need to be processed for molecular identification or phylogenetics (Dighton et al. 2005). Our developed protocol would be of great help particularly dealing with the large number of fungal samples, as, at a given time 24 different fungal samples can be homogenized in a FastPrep®- 24 tissue homogenizer. This method with the high-throughput potential can significantly speed up the molecular identification and phylogenetics work that would result in enrichment of biodiversity inventory in future. Lastly, the entire procedure of gDNA extraction could be finished within 2.5 hours that will effectively reduce the total time taken for a PCR based downstream applications. The developed protocol would enable us to speed-up the fungal molecular identification services, being offered by our culture collection NFCCI, Pune, India.

\section{Acknowledgment}

We are thankful to The Director, MACS-Agharkar Research Institute for providing the necessary facility to carry out the research work. We are grateful to Dr. Sumit Singh Dagar and Ms. Nikita Mehta for their valuable comments.

\section{References}

Abd-Elsalam KA, Schnieder F, Guo JR. 2003 - A modified DNA extraction minipreparation protocol for Fusarium isolates. Journal of Rapid Methods and Automation in Microbiology $11,75-79$.

Al-Samarrai TH, Schmid J. 2000 - A simple method for extraction of fungal genomic DNA. Letters in Applied Microbiology 30, 53-56.

Amer OE, Mahmoud MA, Samawaty ARMA, Sayed SRM. 2011 - Non liquid nitrogen-based method for isolation of DNA from filamentous fungi. African Journal of Biotechnology 10, 14337-14341.

Ashktorab H, Cohen RJ. 1992 - Facile isolation of genomic DNA from filamentous fungi. Biotechniques 13, 198-200.

Chauhan JB, Swetha PR, Jarullah B, Subramanian RB. 2007 - Isolation and molecular characterization of $\beta$-tubulin gene from Arthrobotrys Musiformis. A nematode trapping fungus. Indian Journal of Biotechnology 6, 404-406.

Dighton J, White JF, Oudemans P. 2005 - The Fungal Community: Its Organization and Role in the Ecosystem, 3rd edn. CRC Press, Boca Raton, FL.

Doyle JJ, Doyle JL. 1987 - A rapid DNA isolation procedure for small quantities of fresh leaf tissue. Phytochemical Bulletin 19, 11-15.

Faggi E, Pini G, Campisi E. 2005 - Use of magnetic beads to extract fungal DNA. Mycoses 48, 37.

Fredricks DN, Smith C, Meier. 2005 - A Comparison of six DNA extraction methods for recovery of Fungal DNA as assessed by quantitative PCR. Journal of Clinical Microbiology 43, 5122-5128.

Frisvad JC, Samson RA. 2004 - Polyphasic taxonomy of Penicillium subgenus Penicillium: A guide to identification of food and air-borne terverticillate penicillia and their mycotoxins. Studies in Mycology 49, 1-174. 
Goodwin DC, Lee SB. 1993 - Microwave miniprep of total genomic DNA from fungi, plants, protists and animals for PCR. Biotechniques 15, 438-444.

Griffin DW, Kellogg CA, Peak KK, Shinn EA. 2002 - A rapid and efficient assay for extracting DNA from fungi. Letters in Applied Microbiology 34, 210-214.

Griffiths LJ, Anyim M, Doffman SR, Wilks M, Millar MR, Agrawal SG. 2006 - Comparison of DNA extraction methods for Aspergillus fumigatus using real-time PCR. Journal of Medical Microbiology 55, 1187-1191.

Karakousis A, Tan L, Ellis D, Alexiou H, Wormald PJ. 2006 - An assessment of the efficiency of fungal DNA extraction method for maximizing the detection of medically important fungi using PCR. Journal of Microbiological Methods 65, 38-48.

Karthikeyan V, Patharajan S, Palani P, Spadaro D, Gullino ML, Garibaldi A. 2010 - Modified simple protocol for efficient fungal DNA extraction highly suitable for PCR based molecular methods. Global Journal of Molecular Sciences 5, 37-42.

Lee SB, Milgroom MG, Taylor JW. 1988 - A rapid, high yield mini-prep method for isolation of total genomic DNA from fungi. Fungal Genetics Newsletter 35, 23-24.

Li SL, Zhou B, Yang LY, Li ZY, Zhang Q, Chen YW. 2002 - An improved method for extracting fungal DNA. Journal of Yunnan University 24, 471-472.

Liu D, Coloe S, Baird R, Pedersen J. 2000 - Rapid Mini-Preparation of Fungal DNA for PCR. Journal of Clinical Microbiology 38, 471.

Löffler J, Hebart H, Bialek R. 1999 - Contaminations occurring in fungal PCR assays. Journal of Clinical Microbiology 37, 1200-1202.

Mendoza DG, Delira RA, Trejol AM, Herrera AP, Díaz LC, Juarez OG, Alarcón A. 2010 - A rapid method for isolation of total DNA from pathogenic filamentous plant fungi. Genetics and Molecular Research 9, 162-166.

Mishra AK, Sharma K, Misra RS. 2008 - Rapid and Efficient Method for the Extraction of Fungal and Oomycetes Genomic DNA. Genes, Genomes and Genomics 2, 57-59.

Mishra IG, Tripathi N, Tiwari S. 2014 - A simple and rapid DNA extraction protocol for filamentous fungi efficient for molecular studies. Indian Journal of Biotechnology 13, 536539.

Moller EM, Bahnweg G, Sandermann H, Geiger HH. 1992 - A simple and efficient protocol for isolation of high molecular weight DNA from filamentous fungi, fruit bodies, and infected plant tissues. Nucleic Acids Research 20, 6115-6116.

Muller FMC, Werner KE, Kasai M, Francesconi A, Chanock SJ, Walsh TJ. 1998 - Rapid extraction of genomic DNA from medically important yeasts and filamentous fungi by high-speed cell disruption. Journal of Clinical Microbiology 36, 1625-1629.

Nawrot U, Wlodarczyk K, Wrobel M, Wasik A, Dobosz T. 2010 - Comparison of the utility of five commercial kits for extraction of DNA from Aspergillus fumigatus spores. Acta ABP Biochimica Polonica 57, 567-571.

O'Donnell K, Sutton DA, Rinaldi MG, Sarver BA, Balajee SA, Schroers HJ, Summerbell RC, Robert VA, Crous PW, Zhang N, Aoki T, Jung K, Park J, Lee YH, Kang S, Park B, Geiser DM. 2010 - Internet-accessible DNA sequence database for identifying fusaria from human and animal infections. Journal of Clinical Microbiology 48, 3708-3718.

Płaza GA, Upchurch R, Brigmon RL, Whitman WB, Ulfig K. 2004 - Rapid DNA Extraction for Screening Soil Filamentous Fungi Using PCR Amplification. Polish Journal of Environmental Studies 13, 315-318.

Prabha TR, Revathi K, Vinod MS, Shanthakumar SP, Bernard P. 2013 - A simple method for total genomic DNA extraction from water moulds. Current Science 104, 345-347.

Sambrook J, Russel DW. 2001- Rapid isolation of yeast DNA. In: Sambrook J, Russell DW (Eds) Molecular Cloning: A Laboratory Manual, 2nd Edn, Cold Spring Harbor Laboratory, New York, pp 631-632. 
Schoch CL, Seifert KA, Huhndorf S, Robert V, Spouge JL, Levesque CA, Chen W, Fungal Barcoding Consortium. 2012 - Nuclear ribosomal internal transcribed spacer (ITS) region as a universal DNA barcode marker for Fungi. Proceedings of the National Academy of Sciences of the United States of America 109, 6241-6246.

Van Burik JAH, Schreckhise RW, White TC, Bowden RA, Myerson D. 1998 - Comparison of six extraction techniques for isolation of DNA from filamentous fungi. Medical Mycology 36, 299-303.

White TJ, Bruns T, Lee S, Taylor JW. 1990 - Amplification and direct sequencing of fungal ribosomal RNA genes for phylogenetics. In PCR Protocols, A Guide to Methods and Applications, eds. Innis MA, Gelfand DH, Sninsky JJ, White TJ, Academic Press, Inc., New York, pp 315-322.

Wu ZH, Wang TH, Huang W, Qu YB. 2001 - A simplified method for chromosome DNA preparation from filamentous Fungi. Mycosystema 20, 575-577.

Xue SJ, Yue TL, Guan J, Yuan YH, Gao ZP. 2006 - An improved method for extracting fungal DNA. Food Research and Development 27, 39-40.

Zhang YH, Wei DS, Xing LJ, Li MC. 2008 - A modified method for isolating DNA from fungus. Microbiology China 35, 466-469.

Zhang YJ, Zhang S, Liu XZ, Wen HA, Wang M. 2010 - A simple method of genomic DNA extraction suitable for analysis of bulk fungal strains. Letters in Applied Microbiology 51, $114-118$ 